Revista Brasileira de Agricultura Irrigada v.14, nº.2, p. 3919 - 3930, 2020

ISSN 1982-7679 (On-line)

Fortaleza, CE, INOVAGRI - http://www.inovagri.org.br

DOI: $10.7127 /$ rbai.v14n101098

Protocolo 1098.20 - 02/07/2019 Aprovado em 08/06/2020

\title{
AGRONOMIC PERFORMANCE OF SUGARCANE AS AFFECTED BY SOURCES AND NITROGEN RATES IN THE BRAZILIAN SAVANNAH REGION
}

\author{
Ana Carolina Oliveira Horschutz ${ }^{1}$, Marconi Batista Teixeira ${ }^{2}$, Edson Cabral da Silva ${ }^{3}$, Frederico \\ Antonio Loureiro Soares ${ }^{4}$, Fernando Nobre Cunha ${ }^{5}$, Fernando Rodrigues Cabral Filho ${ }^{6}$
}

\begin{abstract}
In the different agricultural environments, the productivity of Brazilian sugarcane plantations has been limited, mainly, by the availability of nutrients in the soil, especially nitrogen. The cerrado (savanah) region covers the main Brazilian agricultural frontier, and sugarcane cultivation has advanced to these areas. Based on the hypothesis that the availability of $\mathrm{N}$ in soil influences the agronomic performance of sugarcane, the objective of this study was to evaluate the effects of $\mathrm{N}$ sources and rates on the growth, development and productivity of sugarcane- (CTC-4 variety), cultivated in a dystroferric Red Latosol. The experiment was carried out under field conditions at Fazenda Rio Paraiso II, belonging to the Raízen Usina, in the municipality of Jataí, GO, southwest region of Goiás, Brazil. The experimental design used was a randomized block design, with three replicates, analysed in factorial scheme of $4 \times 2 \times 4$. The treatments were four doses of $\mathrm{N}(0,60,120$ and $180 \mathrm{~kg} \mathrm{ha}^{-1}$ ), two $\mathrm{N}$ fertilizers (urea and ammonium nitrate) and four evaluation periods (210, 250, 290 and 330 days after planting - DAP). The increase of the nitrogen fertilizer rate provided an increase in plant height, stalk diameter and stalk yield. Ammonium nitrate at doses of 60 and $120 \mathrm{~kg}$ $\mathrm{ha}^{-1}$ of $\mathrm{N}$ provided higher yield of stalks than did urea.
\end{abstract}

Key words: Saccharum spp, urea, ammonium nitrate, oxisol.

\section{DESEMPENHO AGRONÔMICO DA CANA-DE-AÇÚCAR ADUBADA COM DOSES E FONTES DE NITROGÊNIO NA REGIÃO DE CERRADO BRASILEIRO}

\footnotetext{
${ }^{1}$ Doutorado em Ciências Agrárias - Agronomia, Instituto Federal Goiano - Campus Rio Verde, Rodovia Sul Goiana, Km 01, CEP: 75.901-170, Rio Verde - GO, e-mail: a.horschutz@ hotmail.com

${ }^{2}$ Eng. Agrônomo, Prof. Dr. em Agronomia, IFGoiano - Campus Rio Verde, e-mail: marconibt@gmail.com ${ }^{3}$ Pós-doutorado em Ciências Agrárias - Agronomia, IFGoiano - Campus Rio Verde, e-mail: edsoncabralsilva@gmail.com

${ }^{4}$ Eng. Agrônomo, Prof. Dr. em Agronomia, IFGoiano - Campus Rio Verde, e-mail: fredalsoares@ hotmail.com ${ }^{5}$ Pós-doutorando em Ciências Agrárias - Agronomia, IFGoiano - Campus Rio Verde, e-mail: fernandonobrecunha@hotmail.com

${ }^{6}$ Doutorando em Ciências Agrárias - Agronomia, IFGoiano - Campus Rio Verde, e-mail: fernandorcfilho10@gmail.com
} 


\section{RESUMO}

Nos diferentes ambientes agrícolas, a produtividade dos canaviais brasileiros tem sido limitada, principalmente, pela disponibilidade de nutrientes no solo, em especial nitrogênio. A região de cerrado abrange a principal fronteira agrícola brasileira, e o cultivo da cana-de-açúcar tem avançado para estas áreas. Partindo da hipótese de que a disponibilidade de $\mathrm{N}$ no solo influencia o desempenho agronômico da cana-de-açúcar, o objetivo deste estudo foi avaliar os efeitos de fontes e doses de $\mathrm{N}$ no crescimento, desenvolvimento e na produtividade de colmos da cana-de-açúcar (variedade CTC4), cultivada em um Latossolo Vermelho distroférrico, fase cerrado. O experimento foi conduzido em condições de campo, na Fazenda Rio Paraiso II, pertencente à Usina Raízen, no município de Jataí, GO, região sudoeste de Goiás, Brasil. O delineamento experimental utilizado foi o de blocos casualizados, com três repetições, analisado em esquema fatorial de $4 \times 2 \times 4$. Os tratamentos foram quatro doses de $\mathrm{N}\left(0,60,120\right.$ e $\left.180 \mathrm{~kg} \mathrm{ha}^{-1}\right)$, duas fontes de $\mathrm{N}$ (ureia e nitrato de amônio) e quatro épocas de avaliação $(210,250,290$ e 330 dias após o plantio - DAP). O aumento da dose de adubação nitrogenada proporcionou aumento da altura de planta, diâmetro do colmo e produtividade de colmos. O nitrato de amônio, nas doses de 60 e $120 \mathrm{~kg} \mathrm{ha}^{-1}$ de $\mathrm{N}$, proporcionou maior produtividade de colmos do que a ureia.

Palavras-chave: Saccharum officinarum, ureia, nitrato de amônia, latossolo.

\section{INTRODUCTION}

Sugarcane (Saccharum spp.) is a socioeconomically important crop in the Brazilian energy scenario. Brazil is the world's largest producer of sugarcane (its derivatives, sugar, and biofuel). Total area harvested with sugarcane in the country, in the 2016/2017, was approximately 9 million hectares. Among sugarcane producing states, Goiás is the second largest producer with $10.3 \%$ (CONAB, 2017). This crop is of great importance for the Brazilian energy sector, as it is an alternative energy source that is environmentally sustainable and renewable. The Cerrado region has increased over the years its importance in the national scenario of sugarcane cultivation, especially the Goiás state. Among the factors that favored the increase of the numbers in this state, is the great volume of areas with potential for the grown of this of crop and the tropical climate most suitable for the sugarcane production.

The sugarcane production has evolved in recent years; these gains in efficiency are the result of improvements in management practices and technology applied to sugarcane plantations. Nitrogen fertilization stands out as one of the cultural practices of higher demand for sugarcane research, because $\mathrm{N}$ studies present very variable and often even contradictory results (KORNDÖRFER et al., 2002). However, there are many studies that show the importance of $\mathrm{N}$ in the sugarcane crop (WIEDENFELD \& ENCISO, 2008, SILVA et al., 2009; FRANCO et al., 2011).

Sugarcane has been undergoing changes in the management practices in the field. The main change is perhaps the transition from manual harvesting with the previous burning of the sugarcane to mechanized harvesting without fire extinguishing. Harvesting without burning ensures the permanence on soil the crops residues (dry leaves and pointers) and changes the dynamics of $\mathrm{N}$ mineralizationimmobilization in the sugarcane stalks. In addition, N-organic mineralization has a positive effect on plant nutrition (VITTI et al., 2011; HOLST et al., 2012; TRIVELIN et al., 2013). In the literature, several studies show the importance of nitrogen in sugarcane (SILVA et al., 2009), mainly because it is a constituent part of nucleic acids and amino acids, precursors of proteins, directly or indirectly participating in several biochemical processes (SILVA et al., 2006). In some studies, it has been verified, the effect of nitrogen fertilization on sugarcane yields and on growth parameters (SILVA et al., 2006; CUNHA et al., 2016). 


\section{AGRONOMIC PERFORMANCE OF SUGARCANE AS AFFECTED BY SOURCES AND NITROGEN RATES IN THE BRAZILIAN SAVANNAH REGION}

According to Trivelin et al. (1995) for a yield of $100 \mathrm{t} \mathrm{ha}^{-1}$ of stalks, the crop extracts around $200-300 \mathrm{~kg} \mathrm{ha}^{-1}$ of $\mathrm{N}$. The amounts of $\mathrm{N}$ exported by the stalks are similar or even lower than the nutrient applied along the cycle, not counting the $\mathrm{N}$ losses from the soilplant system (CANTARELLA et al., 2007). The concentrations of $\mathrm{N}$ in the plant are generally variable, and the extraction and export varied between varieties (OLIVEIRA et al., 2011) and water availability (GAVA et al., 2010; KÖLLN, 2012). The N use efficiency or recovery of $\mathrm{N}$ applied as fertilizer by sugarcane or other vegetables depends on the form and place of application, precipitation, variety (OLIVEIRA et al., 2011) and applied N source (BASANTA et al., 2003).

At present, the $\mathrm{N}$ rates recommended for cane-plant fall short of the actual crop requirements. Considering that soil $\mathrm{N}$ losses reduce the nutrient concentration available to the crop, especially in the system with straw maintenance and in low or medium fertility soils, in this $\mathrm{N}$ deficiency condition, has no way of expressing its productive potential.

Several factors can explain the low responses to $\mathrm{N}$ in cane-plant, such as the mineralization of soil organic matter and the cultural remains of the crop during the soil rotation in the sugarcane reforestation (CANTARELLA et al., 2007). Other justifications for the low response of the caneplant to $\mathrm{N}$ include greater vigor of the caneplant root system compared to that of the first ratoon sugarcane, the improvement of soil fertility associated with liming and fertilization made in sugarcane fallow period, biological $\mathrm{N}$ fixation, the lower initial nutrient demand of the cane-plant, the losses of $\mathrm{N}$ fertilizers by leaching and the contribution of the $\mathrm{N}$ stocked on the seed piece sugarcane (VITTI et al., 2008; URQUIAGA et al., 2012).
Based on the hypothesis that $\mathrm{N}$ availability in soil influences the agronomic performance of sugarcane, the objective of this study was to evaluate the effects of $\mathrm{N}$ sources and rates on the growth, development and productivity of sugarcane (CTC-4 variety), cultivated in a dystroferric Red Latosol.

\section{MATERIAL AND METHODS}

The experiment was carried out under field conditions, during the 2014/2015 growing season, in an area at Rio Paraiso II Farm (Raízen plant Mill), in the municipality of Jataí - GO. The geographical coordinates of the site are $17^{\circ} 44^{\prime} 2.62$ "S and $51^{\circ} 39^{\prime} 6.06^{\prime \prime} \mathrm{W}$, with an average altitude of 907 meters. According to the classification of Köppen \& Geiger (1928), the climate of the place is type Aw, tropical, with rainfall from October to April, and dry season from May to September. The maximum temperature ranges from $35^{\circ}$ to $37^{\circ} \mathrm{C}$ and the minimum of 12 to $15^{\circ} \mathrm{C}$ (in the winter there are occurrences of up to $5^{\circ}$ degrees).

The annual precipitation reaches approximately $1,800 \mathrm{~mm}$, but poorly distributed throughout the year. Daily water balance and meteorological data are presented in Figure 1. The soil of the experimental area is classified as Dystropherric Typic Rhodic Hapludox soil and dystroferric Red Latosol, very loamy, cerrado (savanah) phase (SANTOS et al., 2013).

The experimental area has a history of renovation of the sugarcane plantation of seven years of cultivation. The chemical, physical granulometry and textural classification, and soil water content of the samples collected before the installation of the experiment are described in Table 1. 


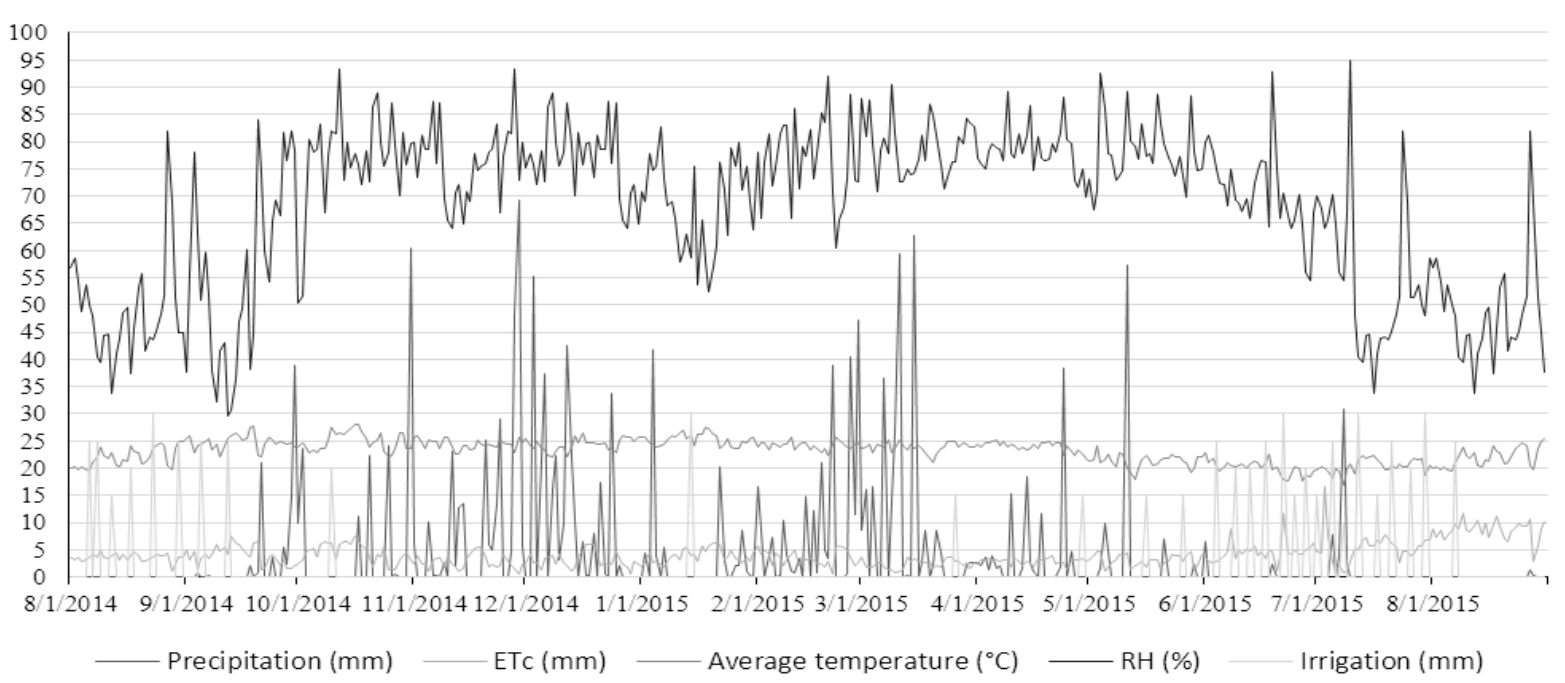

Figure 1. Daily water balance in the experimental period: data on temperature, rainfall, relative humidity $(\mathrm{RH})$, irrigation and ETc, Jataí - GO, Brazil, harvest 2014/15.

The experimental design was a randomized block, analyzed in a $4 \times 2$ factorial scheme, with three replicates. The treatments were four $\mathrm{N}$ rates $(30,60,120$ and $180 \mathrm{~kg} \quad \mathrm{~N} \quad$ ha $^{-1}$ ); two $\mathrm{N}$ fertilizers (urea and ammonium nitrate). For the biometric growth, four periods $(210,250$, 290 and 330 days after planting - DAP) were evaluated, that is, a $4 \times 2 \times 4$ factorial scheme.

Table 1. Chemical, physical, granulometry and soil textural classification, and soil water content of the experimental area, 0.00-0.20 and 0.20-0.40 m depth, Jataí - GO, Brazil, 2014/15 harvest.

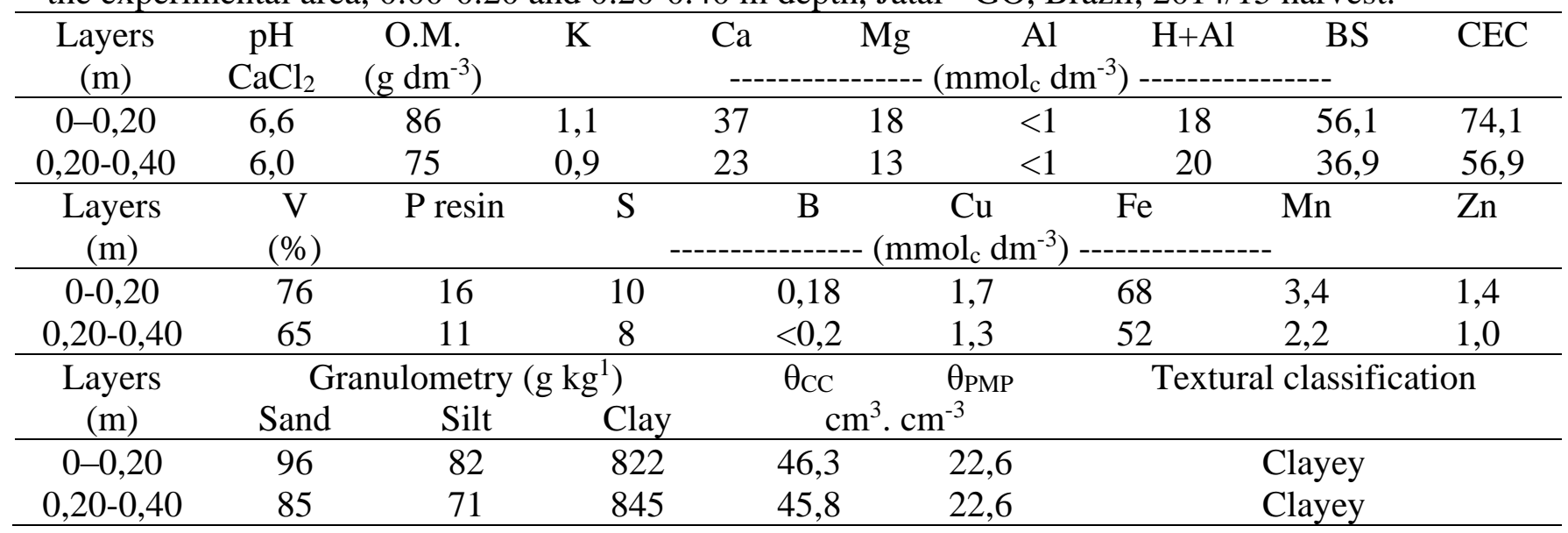

The plots consisted of six lines of sugarcane, $5 \mathrm{~m}$ long, spaced $1.50 \mathrm{~m}$ apart. The assessed area was represented by three lines of 3 meters linear, in the three central lines of each plot, scoring $1.0 \mathrm{~m}$ at each end.

Soil preparation was performed by the conventional system, by means of plowing and harvesting, followed by opening of the machining planting grooves, on 09/20/2014, according to the experience of the plant the number of buds per meter, according to the recommendations for the respective variety, distributing seed piece with average, of 15 gems per linear meter. The variety used was the CTC-4. $\mathrm{N}$ fertilization treatments, in the form of urea, were divided into three applications from 60 days after planting, applied to the haul, on the line side $(0.20 \mathrm{~m})$, contrary to the slope of the land.

All treatments were fertilized at planting with phosphorus (100 kg ha-1 of $\left.\mathrm{P}_{2} \mathrm{O}_{5}\right)$, as triple superphosphate, potassium $\left(80 \mathrm{~kg} \mathrm{ha}^{-1}\right.$ of $\mathrm{K}_{2} \mathrm{O}$ ), as potassium chloride, and micronutrients, according to the results from 
soil analysis and recommendation of Sousa \& Lobato (2004). The herbicides, insecticides, fungicides, and other products for control of invasive plants, pests and diseases were used whenever necessary.

At 210, 250, 290 and 330 DAP two tillers were collected in the central lines to evaluate the variables plant height $(\mathrm{PH})$ and stalk diameter (SD), according to Benincasa (2003); the plant height was measured using a tape measure, from the soil to the collar of the leaf +1 (sheet +1 is the one that can be completely visualized the collar), and expressed in $\mathrm{m}$; The stalk diameter was determined with the aid of a pachymeter at the base of the plant, and expressed in $\mathrm{mm}$.

The sugarcane ${ }^{\circ}$ Brix was monitored in the field during the last four weeks prior to harvest. For the rational determination of the sugarcane harvest point, the parameter known as the Maturation Index (MI) was determined in the field, using a portable refractometer. The MI values are: (a) less than 0.60 for green sugarcane; (b) between 0.60 and 0.85 for sugarcane in the process of maturation; (c) between 0.85 and 1 for mature sugarcane; and (d) greater than 1 for sugarcane in the process of sucrose decline (ROSSETTO, 2012).

Harvesting was performed on 20/10/2015, stalk yield (SY) was determined by total weighing of stalks present in the respective subplots, quantifying the weight of stalks present in $2 \mathrm{~m}$ of the two central lines, whose value was extrapolated to $\mathrm{tha}^{-1}$. For this, the cut was made as close as possible to the soil. The stalks were then untidy and had the pointer highlighted. They were then weighed in a hook-type digital scale, with a Soil Control mark (accuracy $=0.02 \mathrm{~kg}$ ), with a capacity of $50 \mathrm{~kg}$. The number of industrializable tillers averaged per linear meter was determined by counting the number of plants in $2 \mathrm{~m}$ of the two plot lines.
The data obtained were analyzed statistically by variance analysis and when detected significant effects (F test $5 \%$ of probability), they were adjusted to regression equations. Linear and quadratic components were tested and chosen the model with larger significant degree.

The means for $\mathrm{N}$ source (urea and ammonium nitrate) were compared by the Tukey test to $5 \%$ of probability. The statistical analyses were carried out using the SISVAR ${ }^{\circledR}$ (FERREIRA, 2011).

\section{RESULTS AND DISCUSSION}

It is observed that plant height $(\mathrm{PH})$ and stalk diameter (SD) were significantly influenced by doses of nitrogen (DN), as well as by the evaluation period.

The higher $\mathrm{N}$ rates provided higher $\mathrm{PH}$, regardless of the source applied (Figure 2A). In the treatments without application of $\mathrm{N}$, the estimate of the $\mathrm{PH}$ was $1.73 \mathrm{~m}$, while with the application of $60 \mathrm{~kg} \mathrm{ha}^{-1}$ of $\mathrm{N}$ the estimate was $1.85 \mathrm{~m}$. At the doses of 120 and $180 \mathrm{~kg} \mathrm{ha}^{-1}$ of $\mathrm{N}$, the estimated $\mathrm{PH}$ were 1.96 and $2.08 \mathrm{~m}$, respectively, which represents an increase in $\mathrm{PH}$ of approximately $16.82 \%$ in relation to the control (without application of $\mathrm{N}$ ).

The $\mathrm{PH}$ also increased by $5,5 \%$ for each $60 \mathrm{~kg} \mathrm{ha}^{-1}$ increase in $\mathrm{N}$ (Figure 2A). The PH estimates for DAP were $1.71 ; 1.81 ; 1.91$ and 2.19 m, respectively, at 210, 250, 290 and 330 DAP (Figure 2B). It can be observed an increase of $21.91 \%$ when $180 \mathrm{~kg} \mathrm{ha}^{-1}$ was applied in relation to the treatment without application of $\mathrm{N}$. Beneficial effects of the application of nitrogen in the plant growth, in several phenological stages of of sugarcane were observed by several studies (ALVES, 2014; OLIVEIRA et al., 2014, SOUZA et al., 2015). 

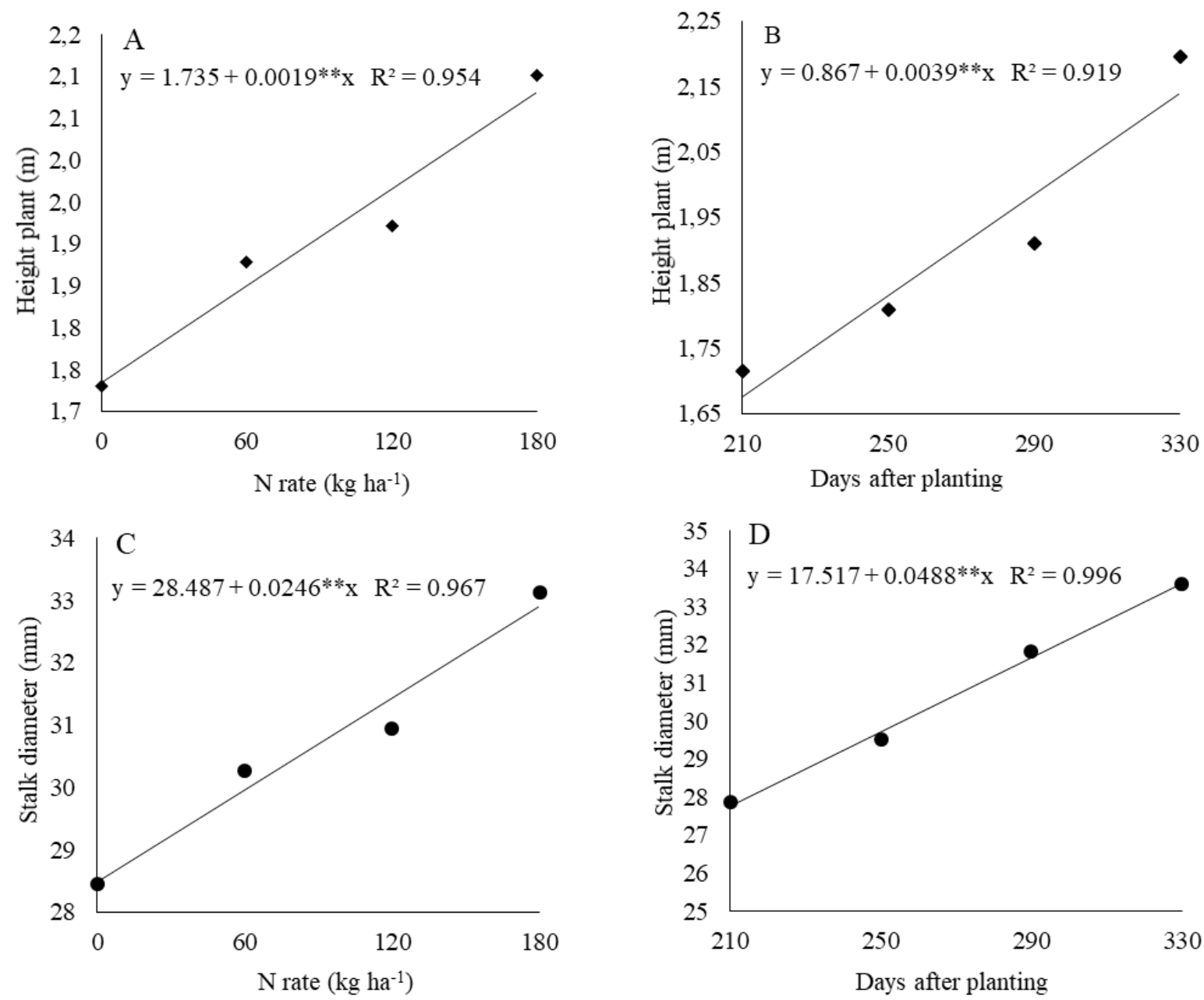

Figure 2. Height of the sugarcane plant as a function of nitrogen doses (A), days after planting (B) and stalk diameter as a function of nitrogen (C) and days after planting (D), in the municipality of Jataí, GO, Brazil, harvest $2014 / 2015 .{ }^{* *}$ and ${ }^{*}$ significant respectively at $1 \%$ and $5 \%$ of probability by the test $\mathrm{F}$.

Nitrogen fertilization has promoted increases in plant height and stalk diameter of sugarcane (SCUDELETTI; LONGATTO, 2015; RIBEIRO, 2016), with positive effects on stalk yield (OLIVEIRA et al., 2010). McCray et al. (2014) add that the effect of $\mathrm{N}$ response on stalk yield can be explained physiologically by changes in plant growth, number of tillers, and biomass production.

A number of studies have shown the importance of nitrogen for sugarcane (SILVA et al., 2009; OLIVEIRA et al., 2010), mainly because it is a constituent part of nucleic acids and amino acids, precursors of proteins, directly or indirectly participating in several (EPSTEIN; BLOOM, 2006), whose nutrient is part of the chlorophyll molecule, with reflexes in the processes of photosynthesis, division and cell expansion (MALAVOLTA et al., 1996).
For the SD variable, the application of $\mathrm{N}$ provided an increase of $13.55 \%$, from the lowest to highest dose of N. For the treatment without application of $\mathrm{N}$, the estimate value of SD was $28.02 \mathrm{~mm}$, while with the application of $60 \mathrm{~kg} \mathrm{ha}^{-1}$ of $\mathrm{N}$, the estimate was $29.67 \mathrm{~mm}$. At the highest doses of $\mathrm{N}(120$ and $180 \mathrm{~kg}$ ha ${ }^{1}$ ), the estimated SD were 31.35 and 33.00 $\mathrm{mm}$, respectively (Figure 2C). The SD also increased by $4,5 \%$ for each $60 \mathrm{~kg} \mathrm{ha}^{-1}$ increase in N. Plant height of $2.05 \mathrm{~m}$ and stalk diameter of $27.6 \mathrm{~mm}$ of sugarcane fertilized with $92 \mathrm{~kg}$ $\mathrm{ha}^{-1}$ of nitrogen were observed by Sime (2013). Nitrogen fertilization, in general, has promoted increases in plant height and stalk diameter of sugarcane (ROCHA, 2013; SCUDELETTI; LONGATTO, 2015; RIBEIRO, 2016).

Soomro et al. (2014) observed that higher doses of nitrogen had greater effect on 
plant height $(>244.1 \mathrm{~cm})$ and stalk diameter (> $25 \mathrm{~mm})$. Nitrogen fertilization increases the growth of sugarcane and allows the plants to absorb other nutrients, which favors the internode elongation and stalk growth, which significantly increases the height of the plant (BIANCHINI et al., 2014). The SD as affected by the DAP is presented in Figure 2D, whose estimates were $27.77 ; 29.72 ; 31.67$ and 33.62 $\mathrm{m}$, respectively, at 210, 250, 290 and 330 DAP. The increase of the stalk diameter in accordance with the evaluation stages was also verified in other studies; however, followed by the reduction of this morphological parameter from the 291 days after the cut (OLIVEIRA et al., 2010; RHEIN, 2012). There is an effect significant effect for NF $\mathrm{x}$ DN interaction on stalk yield of sugarcane (PC) stalk. The Figure $5 \mathrm{~A}$ and $5 \mathrm{~B}$ showed that the values for the $\mathrm{N}$ doses $0,60,120$ and $180 \mathrm{~kg} \mathrm{ha}^{-1}$, applied $\mathrm{N}$ as urea, were $91.38 ; 102.75 ; 132.07$ and $187.20 \mathrm{t}$ $\mathrm{ha}^{-1}$, respectively.

For the same $\mathrm{N}$ rates, applied as ammonium nitrate, the respective values were $94.96 ; 128.41 ; 142.00$ and $181.66 \mathrm{t} \mathrm{ha}^{-1}$.Mean values of stalk yield for 60 and $120 \mathrm{~kg} \mathrm{ha}^{-1} \mathrm{~N}$ rates were statistically superior with the use of ammonium nitrate when compared to the same doses of $\mathrm{N}$ as urea, equivalent an increase of 23.36 and $25.01 \%$, respectively (Figure 5A).
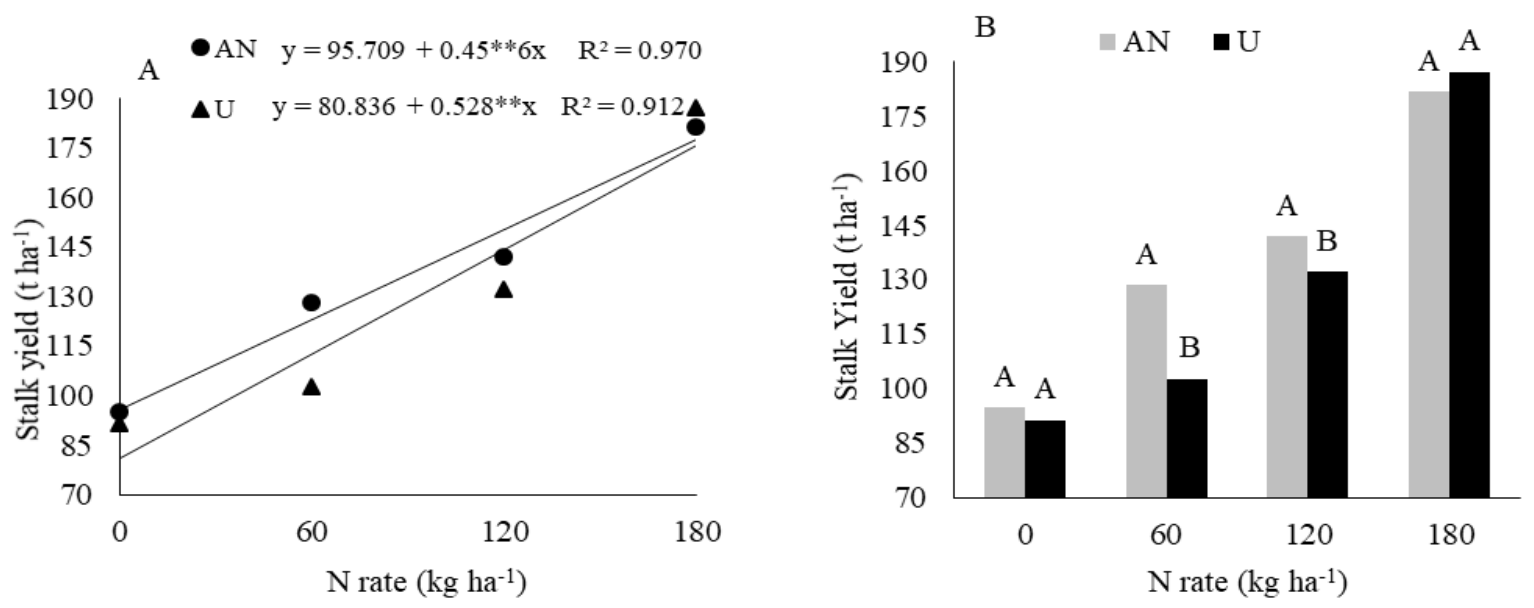

Figure 5. Stalk yield of sugarcane (CTC-4) (cane-plant), (A) and (B) interaction sources x doses, Jataí-GO, Brazil, harvest $2014 / 2015{ }^{* *}$ and ${ }^{*}$ significant respectively at $1 \%$ and $5 \%$ of probability according to test $\mathrm{F}$.

Roy et al. (2006) and Franco et al. (2010), evaluating the productivity of sugarcane plant in relation to nitrogen fertilization, verified that there was an increase in productivity, and also add that high yields are frequently associated with high doses of $\mathrm{N}$. For both sources, with increasing doses of $\mathrm{N}$ occurred an increase in $\mathrm{CP}$, as can be observed in Figure 5B, whose source of ammonium nitrate provided the highest estimated means, except for the dose of $180 \mathrm{~kg} \mathrm{ha}^{-1}$ of $\mathrm{N}$.

The dose of $120 \mathrm{~kg} \mathrm{ha}^{-1} \mathrm{~N}$ as urea had a stalk yield increase of $23.77 \%$ when compared to the dose of $60 \mathrm{~kg} \mathrm{ha}{ }^{-1}$, which had its average estimated at $101.57 \mathrm{t} \mathrm{ha}^{-1}$. For the dose of $60 \mathrm{~kg} \mathrm{ha}^{-1}$ of $\mathrm{N}$, as ammonium nitrate, the mean estimated stalk yield was $121.52 \mathrm{t}$ $\mathrm{ha}^{-1}$, whose increase was $19.96 \%$ when compared to the absence of $\mathrm{N}$ application fertilizer, which had the estimated average stalk yield of $97.26 \mathrm{t} \mathrm{ha}^{-1}$. On the other hand, the dose of $120 \mathrm{~kg} \mathrm{ha}^{-1}$ of $\mathrm{N}$ provided an increase in stalk yield of $18.38 \%$, when compared to the dose of $60 \mathrm{~kg} \mathrm{ha}^{-1}$ of $\mathrm{N}$, the estimated mean PC for the $120 \mathrm{~kg} \mathrm{ha}^{-1}$ dose of $\mathrm{N}$ ratio was $148.89 \mathrm{t} \mathrm{ha}^{-1}$.

Korndörfer et al. (2002) obtained mean increases of $10 \mathrm{tha}^{-1}$ with the application of 60 $\mathrm{kg} \mathrm{ha}^{-1}$ of $\mathrm{N}$ and Castro et al. (2014) obtained increments of up to $21 \%$ in sugarcane plant productivity when $130 \mathrm{~kg} \mathrm{ha}^{-1}$ of $\mathrm{N}$.

Nitrogen fertilization promotes an increase in sugarcane plant productivity, being important the addition and increase of $\mathrm{N}$ 
mineral doses to guarantee, also, vigor and high productivity of sugarcane (FORTES et al., 2013).

Factors such as high values of experimental errors associated with field fertilization trials and the evaluation of the results of isolated trials with small increases in productivity due to nitrogen fertilization lead many technicians to consider that cane-plant can exempt the application of nitrogen fertilizer (VITTI et al., 2007). In this context, considering the high costs and the inconsistency of responses obtained in sugarcane with nitrogen fertilization, it is fundamental to develop agricultural practices and the search for alternative sources that aim at the best use of $\mathrm{N}$ by sugarcane (FRANCO et al., 2010).

In Brazil, many studies have shown increases in cane-plant productivity associated to nitrogen fertilization (FRANCO et al., 2010; FORTES et al., 2011; FORTES et al., 2013); however, there are divergences regarding the dose of $\mathrm{N}$ that provides the maximum economic productivity (OTTO et al., 2016). The response of sugarcane to nitrogen fertilization is generally related to the biological fixation of atmospheric nitrogen; leaching losses from fertilizer $\mathrm{N}$; the vigor of the root system; climatic conditions; the improvement of soil fertility, after the reform of the sugarcane fields, associated with liming, mechanical preparation and the incorporation of remains of the previous crop (CARNEIRO et al., 1995; ORLANDO FILHO et al., 1999; URQUIAGA et al., 1992).

Thus, studies in different soil and climatic conditions, such as the Cerrado region, are important, in order to improve the $\mathrm{N}$ recommendation with positive impacts on stalk yield and on the maintenance of $\mathrm{N}$ stocks in the soil, as a consequence of their potential productive long-term.

\section{CONCLUSIONS}

Ammonium nitrate provided higher yields of sugarcane stalks than urea at 60 and $120 \mathrm{~kg} \mathrm{ha}^{-1} \mathrm{~N}$.
Regardless of the source used, the increment of the dose of $\mathrm{N}$ provided an increase in plant height, stalk diameter, with positive effects on stalk yield.

\section{ACKNOWLEDGEMENTS}

The authors wish to thank the National Council for Scientific and Technological Development $(\mathrm{CNPq})$, the Coordination for the Improvement of Higher Education Personnel (Capes), the Foundation for Research Support of the State of Goiás (FAPEG) and the Goiano Federal Institute Rio Verde Campus, financial and structural support.

\section{REFERENCES}

ALVES, B. A. Desempenho agronômico e produtividade de soqueira de cana-deaçúcar submetida a diferentes níveis de água e nitrogênio. Dissertação (Mestrado) Instituto Federal Goiano - Campus Rio Verde. 2014, 66p.

BASANTA, M. V.; DOURADO-NETO, D.; REICHARDT, K.; BACCHI, O. O. S.; OLIVEIRA, J. C. M.; TRIVELIN, P. C. O.; TIMM, L. C.; TOMINAGA T. T.; CORRECHEL, V.; CASSARO, F. A. M.; PIRES, L. F.; MACEDO, J. R. Management effects on nitrogen recovery in a sugarcane crop grown in Brazil. Geoderma, v.116, n.12, p.235-248,2003.

https://doi.org/10.1016/S00-167061(03)0103-

BENINCASA, M. M. P. Análise de crescimento de plantas: noções básicas. 2. ed. Jaboticabal: FUNEP, 2003. 41 p. BLACKMAN, V. H. The compound interest law and plant growth. Annals of Botany, London, v. 33, p. 353-60, 2003.

BIANCHINI, A.; VALADÃO JUNIOR, D.D.; ROSA, R.P.; COLHADO, F.; DAROS, R.F. Soil chiseling and fertilizer location in sugarcane ratoon cultivation. Engenharia 
Agrícola,

p.57-

65 ,

v.34,

2014.

http://dx.doi.org/10.1590/S0100-

69162014000100007.

CANTARELLA, H. Uso eficiente de fertilizantes nitrogenados: Uso eficiente de nitrogênio em novos fertilizantes no Brasil. Informações Agronômicas IPNI, n.120, p.1213, 2007.

CARNEIRO, A. E. V.; TRIVELIN, P. C. O.; VICTORIA, R. L. Utilização da reserva orgânica e do nitrogênio do tolete de plantio (colmo-semente) no desenvolvimento da canaplanta. Scientia Agricola, Piracicaba, v. 53, n. 2, p. 199-209, 1995.

CONAB. Acompanhamento de safra brasileira: cana-de-açúcar, terceiro levantamento, dezembro/2017. Disponível: http://www.conab.gov.br/OlalaCMS/uploads/a rquivos/ boletim_cana -3o_lev_-_16-17.pdf > Acesso em : 02 mar. 2018.

CUNHA, F. N.; SILVA, N. F.; SOUSA, A. E. C.; TEIXEIRA, M. B.; SOARES, F. A. L.; VIDAL, V. M. Yield of sugarcane submitted to nitrogen fertilization and water depths by subsurface drip irrigation. Revista Brasileira de Engenharia Agrícola e Ambiental, v.20, n.9, p.841-846, 2016. http://dx.doi.org/10.1590/1807-1929/agriambi.v-20n9p841-846

EPSTEIN, E.; BLOOM, A. J. Mineral nutrition of plants: principles and perspectives. Sunderland: Sinauer Associates, 2006. 400p.

FERREIRA, D. F. Sisvar: a computer statistical analysis system. Ciência e Agrotecnologia, v. 35, n. 6, p. 1039-1042, 2011. http://dx.doi.org/10.1590/S1413705420110006-00001.

FORTES, C.; TRIVELIN, P. C.; VITTI, A. C.; OTTO, R.; FRANCO, H. C. J.; FARONI, C. E. Stalk and sucrose yield in response to nitrogen fertilization of sugarcane under reduced tillage. Pesquisa Agropecuaria Brasileira, v. 48, n. 1, p. 88-96, 2013. http://dx.doi.org/10.1590/S0100-

204X2013000100012.

FORTES, C.; TRIVELIN, P.C.O.; VITTI, A.C.; FERREIRA, D.A.; FRANCO, H.C.J.; OTTO, R. Recovery of Nitrogen $\left({ }^{15} \mathrm{~N}\right)$ by sugarcane from previous crop residues and urea fertilization under a minimum tillage system. Sugar Technology, 13:42-46, 2011. http://dx.doi.org/10.1007/s12355-011-0074-4

FRANCO, H. C. J.; OTTO, R.; FARONI, C. E.; VITTI, A. C.; OLIVEIRA, E. C. A.; TRIVELIN, P.C.O. Nitrogen in sugarcane derived from fertilizer under Brazilian field conditions. Field Crops Research, v. 121, p. 29-41, 2011. https://doi.org/10.1016/j.fcr.2010.11.011.

FRANCO, H. C. J.; TRIVELIN, P. C. O.; FARONI, C. E.; VITTI, A. C.; OTTO, R. Stalk yield and technological attributes of planted cane as related to nitrogen fertilization. Scientia Agricola, v. 67, n. 5, p. 579-590, 2010. http://dx.doi.org/10.1590/S0103901620100005-00012

GAVA, G. J. C.; KÖLLN, O. T.; URIBE, R. A. M.; TRIVELIN, P. C. O.; CANTARELLA, $\mathrm{H}$.

Interação entre água e nitrogênio na produtividade de cana-de-açúcar (Saccharum spp.). In: Crusciol, C. A. (Org.). Tópicos em ecofsiologia da cana-de-açúcar. 1. ed. Botucatu: FEPAF, v. 1, p.49-66, 2010.

HOLST, J.; BRACKINA, R.; ROBINSONA, N.; LAKSHMANANB, P.; SCHMIDTA, S. Soluble inorganic and organic nitrogen in two Australian soils under sugarcane cultivation. Agriculture, Ecosystems and Environment, Amsterdam, v. 155, p. 16-26, 2012. https://doi.org/10.1016/j.a-gee.2012.03.015

KÖLLN, O. T. Interação entre os estresses de nitrogênio e disponibilidade hídrica no 
fracionamento isotópico de ${ }^{13} \mathrm{C}$ e na produtividade em soqueira de cana-deaçúcar. Dissertação (Mestrado em Ciências) Centro de Energia Nuclear na Agricultura, Universidade de São Paulo, Piracicaba, 2012, $104 \mathrm{p}$.

KÖPPEN, W.; GEIGER, R. Klimate der Erde. Gotha: Verlag Justus Perthes. 1928.

KORNDÖRFER, C. M.; KORNDÖRFER, G. H.; CARDOSO, K. Aplicação do silicato de cálcio na recuperação de pastagem degradada de Brachiaria decumbens. In: Reunião Brasileira De Fertilidade Do Solo E Nutrição De Plantas, 25., Rio de Janeiro. Proceedings. Rio de Janeiro: SBCS, 2002. p.811.

MALAVOLTA, E. Manual de nutrição de plantas. Editora Agronômica Ceres, p. 638. 2006.

MCCRAY, J. M.; MORGAN, K. T.; BAUCUM, L.; J. I. S. Sugarcane yield response to nitrogen on sand soils. Agronomy Journal, v. 106, p. 1461-1469, 2014. https://doi.org/10.2134/agronj-13.0513.

OLIVEIRA, E. C. A.; OLIVEIRA, R. I.; ANDRADE, B. M. T.; FREIRE, F. J.; LIRA JÚNIOR, M. A.; MACHADO, P. R. Crescimento e acúmulo de matéria seca em variedades de cana-de-açúcar cultivadas sob irrigação plena. Revista Brasileira de Engenharia Agrícola e Ambiental, v. 14, n. 9, p. 951-960, 2010.

OLIVEIRA, E.C.A.; FREIRE, F.J.; OLIVEIRA, A.C.; SIMÕES NETO, D.E.; ROCHA, A.T.; CARVALHO, L.A. Produtividade, eficiência de uso da água e qualidade tecnológica de cana-de-açúcar submetida a diferentes regimes hídricos. Pesquisa Agropecuária Brasileira, Brasília, v.46, n.6, p.617-625, 2011. http://dx.doi.org/10.1590/S0100-

204X2011000-600007

OLIVEIRA, W. S.; BRITO, M. E. B.; ALVES, R. A. B.; SOUZA, A. S.; SILVA, E.
G. Cultivo da cana-de-açúcar sob fertirrigação com vinhaça e adubação mineral. Revista Verde De Agroecologia E Desenvolvimento Sustentável, v. 9, n. 1, p. 01-05, jan - mar, 2014.

ORLANDO FILHO, J.; RODELLA, A. A.; BELTRAME, J. A.; LAVORENTI, N. A. Doses, fontes e formas de aplicação de nitrogênio em cana-de-açúcar. STAB. Açúcar, Álcool e Subprodutos, Piracicaba, v. 17, n. 4, p. 39-41, 1999.

OTTO, R.; CASTRO, S. A. Q.; MARIANO, E.; CASTRO, S. G. Q.; FRANCO H. C. J.; TRIVELIN P. C. O. Nitrogen use efficiency for sugarcane-biofuel production: What is next? Bioenergy Research, p. 1-8, 2016. https://doi.org/10.1007/s12155-016-9763-x.

RHEIN, A. F. L. Produtividade e qualidade da cana-de-açúcar sob doses de nitrogênio via fertirrigação subsuperficial por gotejamento. Tese - Universidade estadual paulista "Júlio de Mesquita Filho" - UNESP. Botucatu-SP. 2012, 117p.

RIBEIRO, D. S. Crescimento inicial da cana-de-açúcar em função de doses de adubos nitrogenados revestidos com micronutrientes ou não. Universidade Federal de Uberlândia UFU. 2016, 35p.

ROCHA, F.L.R. Análise dos fatores de risco do corte manual e mecanizado da cana-deaçúcar no Brasil segundo o referencial de promoção da saúde. Universidade de São Paulo; Escola de Enfermagem de Ribeirão Preto, 2013.

ROSSETTO, R. Maturação da cana-deaçúcar. 2012. Disponível em: http://www.agencia.cnptia.embrapa.br/. Acesso em: 10 jan. 2017.

ROY, R. N; FINCK, A.; BLAIR, G. J.; TANDON, H. L. S. Plant nutrition for food security. A guide for integrated nutrient management. In: Food and Agriculture 
Organization of the United Nations, 2006, 249p.

SANTOS, H. G.; JACOMINE, P. K. T.; ANJOS, L. H. C.; OLIVEIRA, V. A.; OLIVEIRA, J. B.; COELHO, M. R.; LUMBRERAS, J. F.; CUNHA, T. J. F. (Ed.). Sistema brasileiro de classificação de solos. 3.ed. Rio de Janeiro: Embrapa Solos, 2013. $353 \mathrm{p}$.

SCUDELETTI, D.; LONGATTO, M. H. Efeito de diferentes adubações com NPK em cana-de-açúcar (Saccharum officinarum L.). Revista Científica Eletrônica de Agronomia, v. 1, p. 131-139, 2015.

SILVA, A. B.; DANTAS NETO, J.; FARIAS, C. H. A.; AZEVEDO, C. A. V. Rendimento e qualidade da cana-de-açúcar irrigada sob adubações de nitrogênio e potássio em cobertura. Revista Caatinga, Mossoró, v. 22, n. 3, p. 236-241, 2009.

SILVA, A. J. N.; CABEDA, M. S. V.; CARVALHO, F. G. Matéria orgânica e propriedades físicas de um Argissolo Amarelo Coeso sob sistemas de manejo com cana-deaçúcar. Revista Brasileira de Engenharia Agrícola e Ambiental, v.10, p.759-585, 2006. http://dx.doi.org/10.1590/S1415-436620060003-00007

SIME, M. Effect of different nitrogen rates and time of application in improving yield and quality of seed cane of sugarcane (Saccharum spp. L.) Variety B41/22. International Journal of Scientific and Research Publications, v. 3, Issue 1, p.7, 2013.

SOOMRO, A.W.; PANHWAR, F. H.; CHANNA, A. R.; AHSAN, M. Z.; MAJIDANO, M. S.; KHASKHELI, F. I.; SIAL, K. B. Effects of sowing time on yield, got and fiber traits of upland cotton (Gossypium hirsutum L.). International Journal of Scientific and Engineering Research, v. 5, n. 12, p. 194-198, 2014.
SOUSA, D. M. G.; LOBATO, E. (Eds). Cerrado: correção do solo e adubação. 2. ed. Brasília: Embrapa Informação Tecnológica/Embrapa-CPA, 2004. 416 p.

SOUZA, J. K. C.; MESQUITA, F. O.; DANTAS NETO, J.; SILVA, M. B. R.; FARIAS, C. H. A.; LIMA, Y. B. Crescimento da cana-de-açúcar submetido a diferentes lâminas de irrigação e adubação com zinco. Agropecuária Científica no Semiárido. v. 11, n. 1, p. 114-119, abr - jun, 2015. http://dx.doi.org/10.30969/acsa.v11i1.528.

TRIVELIN, P.C.O.; FRANCO, H.C.J.; OTTO, R.; FERREIRA, D.A.; VITTI, A.C.; FORTES, C.; FARONI, C.E.; OLIVEIRA, E.C.A.; CANTARELLA, E. Impact of sugarcane trash on fertilizer requirements for São Paulo, Brazil. Scientia Agricola, Piracicaba, v. 70, p. 345-352, 2013. http://dx.doi.org/10.1590/S0103-90162013000500009

TRIVELIN, P.C.O.; VICTORIA， R.L.; RODRIGUES, J.C.S. Aproveitamento por soqueira de cana-de-açúcar de final de safra do nitrogênio da aquamônia ${ }^{15} \mathrm{~N}$ e uréia ${ }^{15} \mathrm{~N}$ aplicado ao solo em complemento à vinhaça. Pesquisa Agropecuária Brasileira, v.30, n.12, p.1375-1385, 1995.

URQUIAGA, S.; CRUZ, K. H. S.; BODDEY, R. M. Contribution of nitrogen fixation to sugar cane: nitrogen-15 and nitrogen-balance estimates. Soil Science Society of America Journal, Madison, v. 56, n. 1, p. 105-114, 1992.

URQUIAGA, S.; XAVIER, R.P.; MORAIS, R.F.; BAPTISTA, R.B.; SCHULTZ, N.; LEITE, J.M.; MAIA e SÁ, J.; BARBOSA, K.P.; RESENDE, A.S.; ALVES, B.J.R; BODDEY, R.M. Evidence from field nitrogen balance and ${ }^{15} \mathrm{~N}$ natural abundance data for the contribution of biological $\mathrm{N}_{2}$ fixation to Brazilian sugarcane varieties. Plant and Soil, Crawley, v.356, p. 5-21, 2012. https://doi.org/10.1007/s11104-011-1-0163 
VITTI, A. C.; FRANCO, H. C. J.; TRIVELIN, P. C. O.; FERREIRA, D. A.; OTTO, R.; FORTES, C.; FARONI, C. E. Nitrogênio proveniente da adubação nitrogenada e de resíduos culturais na nutrição da cana-planta. Pesquisa Agropecuária Brasileira, v. 46, n. 3, p. 287-293, 2011.

VITTI, A. C.; TRIVELIN, P. C. O.; GAVA, G. J. C.; PENATTI, C.; BOLOGNA, I. R.; FARONI, C. E.; FRANCO, H. C. J. Sugar cane yield related to the residual nitrogen from fertilization and the root system. Pesquisa Agropecuária Brasileira, v. 42, p. 249-256, 2007. http://dx.doi.org/10.1590/S0100-204X2007000200014.

WIEDENFELD, B.; ENCISO, J. Sugarcane responses to irrigation and nitrogen in semiarid south Texas. Agronomy Journal, v.100, p.665-671, 2008. http://dx.doi.org/10.2134/agronj2007-.0286 